\title{
Correction to: Genetic and metabolic links between the murine microbiome and memory
}

Jian-Hua Mao ${ }^{1 \dagger}$, Young-Mo Kim ${ }^{2 \dagger}$, Yan-Xia Zhou ${ }^{1,3+}$, Dehong Hu², Chenhan Zhong ${ }^{1}$, Hang Chang ${ }^{1}$, Colin J. Brislawn', Sarah Fansler ${ }^{2}$, Sasha Langley ${ }^{1}$, Yunshan Wang ${ }^{1,4}$, B. Y. Loulou Peisl ${ }^{5}$, Susan E. Celniker ${ }^{1}$, David W. Threadgill ${ }^{6,7}$, Paul Wilmes ${ }^{5}$, Galya Orr ${ }^{2}$, Thomas O. Metz ${ }^{2}$, Janet K. Jansson ${ }^{2^{*}}$ and Antoine M. Snijders ${ }^{1 *}$

\section{Correction to: Microbiome (2020) 8:53 https://doi.org/10.1186/s40168-020-00817-w}

Following publication of the original article [1], the authors reported that Sarah Fansler had been left off the author list in error. The author group has been updated above and the original article [1] has been corrected.

\section{Author details}

${ }^{1}$ Biological Systems and Engineering Division, Lawrence Berkeley National Laboratory, Berkeley, CA 94720, USA. ${ }^{2}$ Earth and Biological Sciences Directorate, Pacific Northwest National Laboratory, Richland, WA, USA. ${ }^{3}$ Marine College, Shandong University, Weihai 264209, China. ${ }^{4}$ Department of Clinical Laboratory, The Second Hospital of Shandong University, Jinan 250033, Shandong, China. ${ }^{5}$ Luxembourg Centre for Systems Biomedicine, University of Luxembourg, 7, Avenue des Hauts Fourneaux, L-4362 Esch-sur-Alzette, Luxembourg. ${ }^{6}$ Department of Veterinary Pathobiology, A\&M University, College Station, Texas, USA. ${ }^{7}$ Department of Molecular and Cellular Medicine Texas, A\&M University, College Station, Texas, USA.

Published online: 28 May 2020

\section{Reference}

1. Mao J-H, Kim Y-M, Zhou Y-X, Hu D, Zhong C, Chang H, Brislawn C, Fansler S, Langley S, Wang Y, Peisl BYL, Celniker SE, Threadgill DW, Wilmes P, Orr G, Metz TO, Jansson JK, Snijders AM. Genetic and metabolic links between the murine microbiome and memory. Microbiome. 2020;8:53 https://doi.org/10. 1186/s40168-020-00817-w.

The original article can be found online at https://doi.org/10.1186/s40168020-00817-w.

* Correspondence: Janet.Jansson@pnnl.gov; AMSnijders@|bl.gov

†Jian-Hua Mao, Young-Mo Kim and Yan-Xia Zhou contributed equally to this work.

${ }^{2}$ Earth and Biological Sciences Directorate, Pacific Northwest National Laboratory, Richland, WA, USA

${ }^{1}$ Biological Systems and Engineering Division, Lawrence Berkeley National Laboratory, Berkeley, CA 94720, USA

Full list of author information is available at the end of the article

C C The Author(s). 2020 Open Access This article is licensed under a Creative Commons Attribution 4.0 International License, which permits use, sharing, adaptation, distribution and reproduction in any medium or format, as long as you give appropriate credit to the original author(s) and the source, provide a link to the Creative Commons licence, and indicate if changes were made. The images or other third party material in this article are included in the article's Creative Commons licence, unless indicated otherwise in a credit line to the material. If material is not included in the article's Creative Commons licence and your intended use is not permitted by statutory regulation or exceeds the permitted use, you will need to obtain permission directly from the copyright holder. To view a copy of this licence, visit http://creativecommons.org/licenses/by/4.0/. The Creative Commons Public Domain Dedication waiver (http://creativecommons.org/publicdomain/zero/1.0/) applies to the data made available in this article, unless otherwise stated in a credit line to the data. 